\title{
ENERGY TRANSITION: EMBODIED ENERGY IN CLEAN TECHNOLOGIES AND THE NEED FOR INTERNATIONAL REGULATORY PROACTIVITY
}

\author{
MAGNUS ABRAHAM-DUKUMA \\ Te Piringa - Faculty of Law, University of Waikato, New Zealand
}

\begin{abstract}
The present study is an observation of the absence of policy focus and preparedness to address the greenhouse footprints and eventual climate change implications of some clean energy systems in the energy transition debate. Electric vehicles, wind turbines and photovoltaics constitute sample clean technologies under the study. A technical literature review is the approach for forming an appreciable understanding of the life cycle emissions of the sample clean energy technologies. Content and critical legal analysis are adopted for the examination of international and domestic legal regimes on clean energy sources, with India, China, the United States and the United Kingdom as domestic foci. The results of the study are the reality of supposed clean energy technologies as sources of greenhouse gas emissions, although considerably low compared to fossil fuel sources, and the apparent lack of international and domestic legal mechanisms to address the life cycle emissions of these technologies and the need for proactive policy actions.
\end{abstract}

Keywords: climate change, energy transition, clean energy systems, embodied energy, law.

\section{INTRODUCTION}

It has been observed that current emission pledges of countries are not enough to hold or reduce global average temperature well below $2^{\circ} \mathrm{C}$ [1]. Such an observation further dents the already battered footprints of conventional fossil fuels. Smart energy consumption and exploiting renewable energies are worthy energy transition pathway [2]. Specifically, the need to decarbonise energy-intensive industries by renewable energy to protect the environment may seem a proactive climate action [3]. Efforts by different countries towards climate change mitigation and transition to clean energy is commendable too [4]. However, as climate change is an unprecedented environmental problem, so does it raise novel legal challenges [5]. Irrespective of the laudable potential of renewable energy systems, research [6] shows that the major environmental problem, which they pose, is the embodied greenhouse emission traceable to the construction phase or raw materials used for manufacturing clean energy system components. Another way to conceptualise this is to consider the energy returned on energy invested (EROEI). This refers to the "ratio of the energy produced by an energy-converting device over its lifetime to the amount of primary energy required for the manufacture, transport, construction, operation and decommissioning of the device" [7]. The energy invested in this respect refers to the energy requirements for the manufacture of components, installation, maintenance and decommissioning of the energy system. This calls for a cautious evaluation of any utopian vision or ambition to build a total clean energy system against the odds of present reality [8]. This research elucidates this issue with an examination of electric vehicles (EVs), wind turbines (WTs), and photovoltaics (PVs), without prejudice to other clean energy sources worthy of consideration. Against this background, the study examines international and domestic legal frameworks for possible provisions bothering on life cycle emissions of these sample clean technologies. 


\section{GREEN TRANSITION AND EMBODIED ENERGY CONCERNS}

\subsection{Electric vehicles and GHG emissions}

The widespread conceptualisation of EVs as a disruptive technology, climate change mitigation and decarbonising tool [9] sounds ambitious, but it is fraught with embodied greenhouse gas (GHG) emissions due to energy mix uncertainties, among other grey issues that merit examination [10]. Over 50\% of the climate change effects of EVs are traceable to the manufacturing stage [11]. In contrast with internal combustion engine vehicles (ICEVs), research [12] shows that electric vehicles (EVs) account for higher emissions during manufacturing stage, generating 10 tons of carbon dioxide $(\mathrm{CO} 2)$, while ICEVs generate 6 tons of $\mathrm{CO} 2$ at production phase. Another study [13] estimates the global warming potential of $\mathrm{EV}$ production to range between 87 to $95 \mathrm{gs}$ of $\mathrm{CO} 2$. The high global warming impact of EVs at manufacturing stage is traceable to energy mix for battery production [14]. This pitches the manufacturing phase environmental and climate change impact of an EV above that of an ICEV (that is a conventional fossil fuel-powered vehicle) [15]. A 2017 research [16] reveals some technical details about EV manufacturing processes relevant to the present research. Firstly, the mineral mining requirements to produce a Li-ion battery for an EV are: spodumene, nickel sulphide ore, manganese carbonate. Secondly, the core material production phase requires aluminium, chromium steel, copper, and polypropylene. Thirdly, the pouch cell production requires cathode, anode, electrolyte, separator, and casing. In all these procedural manufacturing requirements, the cathode manufacturing accounts for the most climate change effect in the battery production phase, hence the need for improvement in the electricity mix for the EV manufacturing industry [16, p. 1259]. The transition to cleaner energy by means of electric vehicles can be more credible if accompanied by cleaner energy mix [17]. Although a 2018 study [18] observes a gradual improvement of the total life cycle GHG potential of EVs, it also acknowledges embodied energy traceable to the supply of electricity and manufacture of EV batteries.

\subsection{Wind turbines and GHG emissions}

Conceptualising wind turbines as perfectly clean energy source may be a myopic view void of consideration of possible greenhouse gas emissions which manufacturing phase of the life cycle accounts for [19]. The embodied energy of a wind turbine refers to the energy requirements for the manufacturing, construction, installation and maintenance phases. When considering multiple wind turbines for a wind farm, other materials and components such as wiring, grid connection, transformers and access roads may also account for embodied energy of the wind farm [19]. Research [20] shows that wind turbine energy system is not entirely clean as different phases of the life cycle of a wind turbine are dependent on fossil fuel, therefore prone to carbon emissions. The installation phase requires the use of heavy-duty machinery to mount the various components. The required equipment/machines run on fossil fuel. Decommissioning phase also uses fossil fuel to power cranes and other heavy-duty equipment for dismantling and transportation to incineration or landfill sites. This process is also an emission factor [20]. In another study [21] to estimate the embodied carbon emissions from 14 wind turbines with rated powers between $50 \mathrm{Kw}$ and $3.4 \mathrm{Mw}$, it was found that the materials and machinery for production ranged between 2,139-2,142 tons of CO2 for each turbine with steel, aluminium, polyester and copper accounting for higher emissions. The study notes that only accounting for the operational emissions of a wind turbine misrepresents the environmental impact of its lifecycle. In comparison with fossil fuel, wind energy is a 
more environmentally friendly energy source, but also has social and environmental footprints with climate change implications [22]. There are projections for technology improvement opportunities (TIOs) in the manufacturing materials and processes for the wind farm industry, with particular respect to an onshore wind farm [23]. Nevertheless, whether the context is for an onshore or an offshore wind farm, it is necessary to pursue a better understanding of ways to enable a cleaner energy transition devoid of (or with very infinitesimal) GHG footprints like conventional fossil fuels [24].

\subsection{Photovoltaic system and GHG emissions}

Photovoltaic (PV) or solar energy conversion is one of the renewable energy systems in the energy transition with great potentials to mitigate GHG emissions [25]. While it may seem clean and portends environmental and economic advantages in comparison with conventional fossil fuels [26], it is also fraught with emission concerns traceable to the use of fossil fuel sources as process energy [27]. Specifically, the emissions associated with the PV system come from the entire energy requirements for extraction of raw materials, purification, panel production and complete module installation [28]. Its generation system consists of cells, electrical and mechanical connections, and mounting; while its production materials include "solar cells of multi-crystalline-silicon (mc-Si), single-crystalline-silicon ( $\mathrm{Sc}-\mathrm{Si}$ ), amorphous-silicon (a-Si), cadmium-telluride (CdTe), copper-indium-diselenide (CIS) and of other thin layer materials" [28]. The primary production phase energy input for PVs comprise mainly non-renewable energy sources: oil and natural gas for electricity and steam [29]. The batteries and panels embody considerable volumes of energy invested at production phase [30]. This electricity mix usually contributes $80 \%$ to $90 \%$ of the total production energy requirement and accounts for GHG emissions of photovoltaics [31]. The extent of fossil fuel invested at the manufacturing stage usually determines emission intensity of the PV system [32]. Earlier studies by Alsema [33], Bankier and Gale [34] estimate the embodied energy for mc-Si module comprising frame, supports and inverter as $5400 \mathrm{MJ} / \mathrm{m} 2 ; 6900 \mathrm{MJ} / \mathrm{m} 2$ for $\mathrm{Sc}-\mathrm{Si}$; and $2400 \mathrm{MJ} / \mathrm{m} 2$ for Thin Film. Much of this embodied energy is primarily traceable to production of the manganese, cobalt and copper contained in the PV battery [35].

\section{INTERNATIONAL LEGAL CONSIDERATIONS}

International legal framework for clean energy appears to be fragmented, comprising different direct and indirect legal mechanisms [36]. The International Renewable Agency (IRENA) Statute [37], the International Energy Charter (IEC) [38] and the Paris Climate Change Agreement (PCCA) [39] are vital legal mechanisms with relevant provisions on energy transition. The promotion of widespread adoption of renewable energy sources forms the key objective of the International Renewable Energy Agency (IRENA) [37]. Similarly, the use of renewable energy sources and clean technologies are among the energy efficiency and environmental protection mechanisms provided for by the IEC [40]. The PCCA clearly acknowledges the deployment of renewable energy as a means of averting the environmental impacts of conventional fossil fuels [39, preamble]. These provisions by the different highlighted international legal instruments are laudable for the energy transition debate, with potential to foster a paradigm shift to a green energy economy globally [41]. More so, international policy on energy and renewables has become a powerful normative force for global energy policymaking throughout the years [42]. However, a keen reading of the provisions referred to above reveals that they make neither provisions on nor consideration of energy investment and the embodied energy requirements of widely acknowledged clean energy systems. It is either there is an apparent ignorance or a blatant disregard and 
undermining of the carbon footprints of supposed clean energy systems by the international legal order. If any of these possibilities is the case, an international legal consciousness of this issue becomes necessary. As we make relentless moves towards energy transition for a better environment, there is also need for comprehensive policy regimes to support and address multi-faceted issues and sustainability concerns associated with emerging energy technologies, at the international and domestic levels [43]. International organisations like the ones highlighted above, with their policy regimes, are well suited to engender consensus on the scientific and policy underpinnings of global challenges [44]. Such consensus can have a positive impact in raising awareness on the issue of embodied energy argued in this paper.

\section{DOMESTIC LEGAL CONSIDERATIONS}

China, the United States (US), India and the United Kingdom (UK) stand as top renewables growth leaders [45]. While China, the US and India stand as the top-three renewables growth leaders globally [45], the UK also stands as a leading renewables giant [46], with a leading position for power generation from offshore wind, generating a total of 6.8 gigawatts (GW) at the end of 2017, ahead of Germany (5.4 GW), China (2.8 GW), Denmark (1.3 GW) and Netherlands (1.1 GW) [46, p. 133]. According to the Climate Policy Initiative (CPI) and IRENA, these countries have also made massive financial investments in renewables [47]. Additionally, there is a positive paradigm shift in environmental agenda in China and India, two countries notorious for high carbon emissions [48]. This trend is not limited to China and India, but extends to the BRICS nations - Brazil, Russia, India, China and South Africa [49]. It is possible that there are other jurisdictions with well-advanced clean energy systems. In fact, Sweden, Costa Rica, Nicaragua, Scotland, Germany, Uruguay, Denmark, Morocco and Kenya are making massive investments in clean energy systems [50]. However, the paper limits its examination to China, the US, India and the UK.

\subsection{China}

The energy legal regime of China makes ample provisions for the use of renewable energy sources in the transition from fossil fuels with no consideration of greenhouse gas emissions footprints of clean energy systems. Particularly, the Chinese Energy Conservation Law [51] provides for state development and utilization of renewable energy sources like solar energy, wind energy among others [51, arts 4 and 11]. There are statutory [51, art 30], and policy supports for financing massive investments, promoting and conducting research and development and use of EVs in place of ICEVs [52]. A latter renewable energy law also makes provisions for promotions, adaptation and incentivizing the commercial development of clean energy sources [53]. Pursuant to the Chinese Renewable Energy Law [54], there exists a regulatory guidance (the Circular) for the industrial development of renewables [54, art 9]. The Circular makes provisions on specifications of different components of renewable energy systems but is silent about the energy invested in the process of manufacturing components, production and eventual installation of the systems. Rather, policy focus is on research and industrial development of the supposed clean energy alternatives to fossil fuel sources. In response to the encouraging regulatory and policy environment, there has been a massive development of renewable energy sources such as wind [55], EVs [56] and photovoltaics [57] in China. However, the regulatory regime on renewables is silent on the climate change implications of energy requirements for the manufacture and installation of the supposed clean energy systems in China. There is room for improvement in the energy conservation laws of China in this respect [58]. 


\subsection{India}

India's renewable energy drive hinges on national desire to divest from significant reliance on fossil fuels, achieving energy independence and climate change mitigation [59]. Years before the emergence of the PCCA in 2015 [39], India already had functional policy instruments for climate change mitigation and renewable energy development. Few are relevant to the present discourse. The Energy Conservation Act [60] provides for energy efficiency [60, s 3], but there is no provision for renewable energy development. The Integrated Energy Policy (IEP) [61], National Action Plan on Climate Change (NAPCC) [62] and the Energy Sector Plan [63] all provide for promoting energy efficiency, with emphasis on renewable energy sources. The different policy mechanisms make provisions for incorporating wind and photovoltaics into India's national energy mix. In fact, the NAPCC was India's national policy response to the 2009 Copenhagen Summit [64]. It is true that the Indian State navigated through the multi-faceted issues of economic growth, potential energy crisis and climate change [65]. Policy focus however was in meeting its surging energy demand [66] and mitigating climate change implications of energy use. These are good objectives and pragmatic solutions for energy security and sustainable development [67]. The different policies may have incentivised an appreciable emerging clean energy market [68]. Other regulatory instruments like the Electricity Act [69] and the Tariff Policy [70] may have also contributed to the development of renewables in India because of their provisions on energy efficiency and renewable energy [71]. Renewable energy has enabled promising energy security and sustainable energy architecture in India [72], but policy instruments seem to be blind to the scientific literature regarding the embodied energy of renewables. This is not to undermine commendable regulatory strides and policy advances made towards climate change mitigation by incentivising investments in and deployment of renewable energy sources in India. The intention is to draw attention to a subtle issue, which the stern eyes of the law should be wary of and possibly address.

\subsection{The United States}

The United States' policy on air pollution control and climate change has gone through a chequered history crisscrossing different legislative enactments [73]. From the mid-1990s until 2018, there have been over 100 policy and statutory enactments on air quality, energy and renewables in the US [74]. From the premier statutory enactment (Air Pollution Control Act 1955) [75] to the major Clean Air Act Amendments of 1990 [76] federal policy has been toward ensuring ambient air quality and mitigating climate change through renewables. However, the examination in this paper is limited to four major policy instruments, being the Energy Policy Act [77], Energy Independence and Security Act [78], American Recovery and Reinvestment Act [79] and the Clean Air Act (As Amended) [80]. The Recovery and Investment Act makes provision for deployment and use and of renewables [81]. It also provides for tax incentives for investment in this respect [81, s. 1101]. However, no provision or related provision addresses the climate change implications of renewables, especially at manufacturing phase. The Energy Policy Act [77] makes provisions for incentivising renewable energy production and increased use of renewables, including solar thermal energy, wind energy, among others. The focus seems to be on optimising renewables for energy security, conservation and efficiency. There is no provision or recognition of the energy invested into manufacturing the components of renewables, especially the energy requirement at the manufacturing phases of wind turbines and solar panels. The Energy Independence and Security Act [82] also makes salient provisions for grants [82, ss. 202, 
207], university-based research and development program [82, s. 234], renewable fuel infrastructure development to retailers and wholesale dealers $[82,244]$ geared towards incentivising the development and use of renewables. Again, there is little regard for the environmental or climate implications of manufacturing phase greenhouse gas emissions of clean energy systems. The Clean Air Act makes very similar provisions for renewable fuel program [82, s. 211 (o)] like the Energy Independence and Security Act. The arguments advanced in respect of the Energy Independence and Security Act apply in equal measure to the Clean Air Act. However, it is important to add that the Regulator (being the Administrator of the Environmental Protection Agency) can optimise the regulatory powers conferred on him by the Clean Air Act to promulgate subsidiary legislation [82, s. 211) (v) (2)] to mitigate the embodied energy implications of renewables, as part of the bigger or broader climate change goal.

\subsection{The United Kingdom}

Climate change and energy security constitute key drivers of the UK's energy transition [83]. Its transition pathways encompass energy governance and technological choices for low-carbon energy systems [84]. Specifically, its legislative/policy portfolio or framework on climate change and renewables comprise multiple legislative enactments and policies such as the Energy Act 2013, Finance Act 2011, Feed-in Tariffs for Renewable Electricity 2014, Carbon Reduction Commitment Energy Efficiency Scheme 2014, Climate Change Act 2008, National Adaptation Programme 2013, the UK Renewable Energy Roadmap and few others [85]. There are also multiple policies (repealed and) in force which directly and indirectly constitute key elements of its clean energy policy framework [86]. However, this paper limits its examination to the Energy Act 2013, the UK Renewable Energy Roadmap 2011, Climate Change Act 2008, and the European Union Renewable Energy Directive 2009, with more focus on the latter two, as they constitute the primary regulatory framework for renewables in the UK [87]. The Climate Change Act [88] is arguably the first statutory mechanism globally (and consequently makes UK the first country) to set legally binding targets for emissions reduction and addressing climate change with its attendant consequences [89]. With its key objectives of improving carbon management, addressing climate change and projecting the UK as a strong global climate action leader, it provides for a short-term $26 \%$ emissions reduction below the 1990 levels [88, s. 5] and a long-term $80 \%$ emissions reduction lower than the 1990 baseline by 2050 [88, s. 1]. Consequently, it makes provisions for use of renewable fuels for transportation as a way of combating the climate change implications of fossil fuels.[88, s. 78] The European Union (EU) Renewable Energy Directive [90] requires the UK to source $15 \%$ of its national energy consumption from renewables by 2020 (and varied targets for other EU Member-States) [90, arts 3(1), 4(1) and ANNEX 1]. Pursuant to this provision, the UK Renewables Policy Framework for Action pursues financial support for investment in renewables, unblocking barriers to delivery, and development of emerging technologies - wind, solar photovoltaics, wave, hydro-electric, etc. [91]. These sentiments also form the directive principles and objectives of the UK's Renewable Energy Roadmap, as projected by the UK Department of Energy and Climate Change (DECC) [92]. Similar to the National Renewable Energy Action Plan (NREAP), the Roadmap identifies investment and deployment of eight clean technologies - onshore wind, offshore wind, renewable transport, marine energy, biomass electricity, biomass heat, ground source and air source heat pumps - policy/action pathways for achieving over $90 \%$ of UK's renewable energy goal for 2020 in a cost-effective way [93], [5]-[6]. The Energy Act [93] makes statutory provisions to incentivise emissions reduction in the UK energy mix. We find specific provisions in its 
recognition of the decarbonisation target set out in the EU Renewables Directive [93, s. 5(2) (e) and (3)]. More directly, Contracts for Difference (CFD), aimed at decarbonising electricity generation, capacity market and related functions constitute the cardinal features of the electricity market reform contemplated by the Act [93, s. 6]. Renewables Obligations (RO) place statutory duty on electricity companies to source increasing percentage of electricity generation from renewables [93, s. 32]. These legislative and policy incentives in the foregoing no doubt represent a good regulatory framework for achieving emissions reduction and addressing climate change at a national level [94]. The Climate Change Act in particular has the status of climate constitutionalism, the first of its kind globally [95]. The entire policy mix has been relatively successful in incentivising increased investment in renewables for the purposes of emissions reduction and less reliance on fossil fuels for energy needs [96], even if there is need for reduced renewables generating costs [96]. Further evidence in this respect is UK's position as an offshore wind energy leader [46], and one of the top 10 renewables financing countries [47]. Additionally, there are quite commendable low carbon, renewable and energy efficiency projects across the over 400 local authorities in the UK [97]. However, a careful examination reveals that there seems to be no provision or coverage of embodied energy concerns of renewable energy technologies in the entire policy mix. Policy focus seems to be on emissions reduction from fossil fuel related energy generation and distribution companies. It is also good to think about the implicit or explicit environmental implications of renewables to avoid passing them off as perfectly or completely clean energy systems.

As energy technologies are evolving, there is need for a coordinated policy approach for policy support and the right regulatory framework. It is also important that policy measures at international and domestic fronts keep pace with technological advancement by legislative reviews of existing laws or entirely new policy measures to address seeming environmental and multi-facetted concerns associated with technologies not envisaged or contemplated by the current state of law. The law should be sensitive to innovation and technological advancements and reinvent itself accordingly [98]. At the domestic level, as the framer of innovation [99], the state has a role to play in addressing embodied energy concerns through innovative regulations. No doubt, there has been a growth of policy measures to incentivise renewable projects across diverse jurisdictions due to their clean energy potentials [100]. Irrespective of these, effective regulation is still necessary for addressing likely environmental and safety concerns [101].

\section{CONCLUSIONS}

From a complete life cycle perspective, touted clean energy systems such as wind turbines, electric vehicles and photovoltaics are not entirely clean. They do not totally obviate the environmental concerns associated with conventional fossil fuels. Thus, rather than representing them as entirely clean energy alternatives, it may be safer to assert that they imply lower global warming potentials in comparison with conventional fossil fuels. At the realm of international law, there is lack of policy provision or initiative to address the climate change implications of energy investment into these supposed clean technologies. The situation is similar in leading renewables jurisdictions such as China, India, the US and the UK, irrespective of their emerging legal frameworks on renewables. As innovation snowballing takes centre stage in the energy transition process, the law should also reinvent itself internationally and domestically and be proactive in envisaging and addressing likely or unanticipated challenges like embodied energy. 


\section{ACKNOWLEDGEMENTS}

The paper was written during the course of a doctoral research project funded by the University of Waikato, Hamilton, New Zealand and was supported by the Section on Energy, Environment, Natural Resources and Infrastructure Law (SEERIL) of the International Bar Association (IBA).

\section{REFERENCES}

[1] Peters G.P. et al., Key indicators to track current progress and future ambition of the Paris Agreement. Nature Climate Change, 7, pp. 118-122, 2017.

[2] Ngo, C. \& Natowitz, J.B., Our Energy Future: Resources, Alternatives and the Environment, 2nd edn. Wiley: New Jersey, pp. 661, 2016.

[3] Ahman, M., Nilsson, L.J. \& Johansson, B., Global climate policy and deep decarbonisation of energy-intensive industries. Climate Policy, 17(5), pp. 634-649, 2017.

[4] Obama, B., The irreversible momentum of clean energy. Policy Forum, 355(6321), pp. 126-129, 2017.

[5] Farber, D.A., Climate policy and the United States system of divided powers: Dealing with carbon leakage and regulatory linkage. Transnational Environmental Law, 3(1), pp. 31-55, 2014.

[6] Gallagher, J. et al., Inventory compilation for renewable energy systems: The pitfalls of materiality thresholds and priority impact categories using hydropower case studies. International Journal of Life Cycle Assessment, 20(12), pp. 1701-1707, 2015.

[7] Lloyd, B. \& Forest, A.S., The transition to renewables: Can PV provide an answer to the peak oil and climate change challenges? Energy Policy, 38(11), pp. 7378-7394, 2010.

[8] Clark, C.T.M. et al., Evaluation of a proposal for reliable lo-cost grid power with $100 \%$ wind, water and solar. Proceedings of the National Academy of Sciences of the United States of America, 114(26), pp. 6722-6727, 2017.

[9] Muraya, N.K. \& Capehart, B.L., Are EVs the digital equivalent of HDTV? Energy Engineering, 122(6), pp. 11-32, 2015.

[10] Jochem, P., Babrowski, S. \& Fichner, W., Assessing $\mathrm{CO}_{2}$ emissions of electric vehicles in Germany in 2030. Transportation Research Part A: Policy and Practice, 78, pp. 68-83, 2015.

[11] Zackrisson, M., Avellan, L. \& Orlenius, J., Life cycle assessment of lithium-ion batteries for plug-in hybrid electric vehicles: Critical issues. Journal of Cleaner Production, 18(15), pp. 1519-1529, 2010.

[12] Requia, W.J., Carbon dioxide emissions of plug-in hybrid electric vehicles: A lifecycle analysis in eight Canadian cities. Renewable and Sustainable Energy Reviews, 78, pp. 1390-1396, 2017.

[13] Hawkins, T.R. et al., Comparative environmental life cycle assessment of conventional and electric vehicles. Journal of Industrial Ecology, 17(1), pp. 53-64, 2012.

[14] Sanfélix, J. et al., Environmental performance of advanced hybrid energy storage systems for electric vehicle applications. Applied Energy, 137, pp. 925-930, 2015.

[15] Casals, L.C. et al., Sustainability analysis of the electric vehicle use in Europe for $\mathrm{CO}_{2}$ emissions reduction. Journal of Clean Production, 127, pp. 425-437, 2016.

[16] Wang, Y., Quantifying the environmental impact of a li-rich high-capacity cathode material in electric vehicles via life cycle assessment. Environmental Science Pollution Research, 24(2), pp. 1251-1260, 2017. 
[17] Miotti, M., Hofer, J. \& Bauer, C., Integrated environmental and economic assessment of current and future fuel cell vehicles. International Journal of Life Cycle Assessment, 22(1), pp. 94-110, 2017.

[18] Wu, Z. et al., Life cycle greenhouse gas emission reduction potential of battery electric vehicle. Journal of Cleaner Production, 190, pp. 462-470, 2018.

[19] Savino, M.M. et al., A new model for environmental and economic evaluation of renewable energy systems: The case of wind turbines. Applied Energy, 189, pp. 739$752,2017$.

[20] Martin, E., The wind turbine: energy, design life-cycle. www.designlife-cycle.com. Accessed on: 5 Jan. 2019.

[21] Smoucha, E.A. et al., Life cycle analysis of the embodied carbon emissions from 14 wind turbines with rated powers between $50 \mathrm{Kw}$ and $3.4 \mathrm{Mw}$. Journal of Fundamentals of Renewable Energy and Applications, 6(4), pp. 1, 2016.

[22] Kaldellis, J.K. et al. Environmental and social footprint of offshore wind energy: comparison with onshore counterpart. Renewable Energy, 92, pp. 543-556, 2016.

[23] Ozoemena, M., Cheung, W.M. \& Hasan, R., Comparative LCA of technology improvement opportunities for a 1.5-MW wind turbine in the context of an offshore wind farm. Clean Technologies and Environmental Policy, 20(1), pp. 173-190, 2018.

[24] Duic, N., Is the success of clean energy guaranteed? Clean Technology Environment Policy, 17(8), pp. 2093-2100, 2015.

[25] Nikolić, D. et al., Optimization of photovoltaics panels area at Serbian zero-net energy building. Journal of Renewable and Sustainable Energy, 5(4), pp. 041819-1, 2013.

[26] Ardente, F. et al., life cycle assessment of solar technologies. Sustainability Assessment of Renewables-Bases Products: Methods and Case Studies, eds J. Dewulf, S.D. Meester \& R.A.F, Alvarenga, Wiley: West Sussex, pp. 241, 2016.

[27] Azzopardi, B. and Mutale, J., Life cycle analysis for future photovoltaic systems using hybrid solar cells. Renewable and Sustainable Energy Reviews, 14, p. 1130, 2010.

[28] Burg, B.R. et al., Effects of radiative forcing of building integrated photovoltaic systems in different urban climates. Solar Energy, 147, pp. 399-405, 2017.

[29] Fu, Y., Liu, X. \& Yuan Z., Life cycle assessment of multi-crystalline photovoltaic (PV) systems in China. Journal of Cleaner Production, 86, pp. 180-190, 2015.

[30] Mason, I.G. \& Miller, A.J.V., Energetic and economic optimisation of islanded household-scale photovoltaic-plus-battery systems. Renewable Energy, 96, pp. 559$573,2016$.

[31] Wong, J.H., Royapoor, M. and Chan, C.W., Review of life cycle analysis and embodied energy requirements of single-crystalline and multi-crystalline silicon photovoltaic systems. Renewable and Sustainable Energy Reviews, 58, pp. 608-618, 2016.

[32] Fthenakis, V., Life cycle assessment of photovoltaics. Photovoltaic Solar Energy, eds R. Reinders et al., Wiley: West Sussex, pp. 646, 2017.

[33] Alsema, E.A., Energy pay-back time and $\mathrm{CO}_{2}$ emissions of PV systems. Progress in Photovoltaics: Research and Applications, 8(1), pp. 17, 2010.

[34] Bankier, C. \& Gale S., Energy payback of roof mounted photovoltaic cells. Energy Bulletin, pp. 5, 2006.

[35] Bilich, A. et al., Life cycle assessment of solar photovoltaic microgrid systems in offgrid communities. Environmental Science and Technology, 51(2), pp. 1043-1052, 2017. 
[36] Am, M.W. \& Drake, L., International law and the renewable energy sector. The Oxford Handbook of International Climate Change Law, eds C.P. Carlarne., K.R. Gray \& Tarasofsky, OUP, pp. 357, 2016.

[37] The Statute of IRENA signed in Bonn on 26 January 2009.

[38] The International Energy Charter, adopted 20 May 2015 and entered into force 4 November, 2016.

[39] The Paris Agreement under the United Nations Framework Convention on Climate Change, adopted 12 December 2015 and entered into force 4 November 2016.

[40] IEC, Title 1(3), title II art 7.

[41] Gehring, M.W., Legal transition to the green economy. McGill International Journal of Sustainable Development Law and Policy, 12, pp. 135-173, 2016.

[42] Bruce, S., International law and renewable energy: Facilitating sustainable energy for all? Melbourne Journal of International Law, 14(1), pp. 1-36, 2013.

[43] Bradbrook, A.J., Creating law for next generation energy technologies. George Washington Journal of Energy and Environmental Law, 2, pp. 17-38, 2011.

[44] Meyer, T., Global public goods, governance risk, and international energy. Duke Journal of Comparative and International Law, 22, pp. 319-348, 2012.

[45] IEA, Renewables 2017: Analysis and Forecasts to 2022, IEA, 2017.

[46] REN21, Renewables 2018: Global Status Report (Renewable Energy Policy Network for the 21st Century 2018) at 71, at 90 and 109.

[47] CPI and IRENA, Global Landscape of Renewable Energy Finance 2018, IRENA, Abu Dhabi, pp. 27, 2018.

[48] Jayaram, D., A shift in the agenda for China and India: Geopolitical implications for future climate governance. Carbon and Climate Law Review, 9(3), pp. 219-230, 2015.

[49] Sahu, M.K., Energy revolution under the BRICS nations. BRICS Law Journal, 3(1), pp. 34-42, 2016.

[50] The Climate Reality Project, follow the leader: How 11 countries are shifting to renewable energy; The Climate Reality Project.

www.climaterealityproject.org/blog/follow-leader-how-11-countries-are-shiftingrenewable-energy. Accessed on: 4 Dec. 2018.

[51] Energy Conservation Law of the People's Republic of China, No. 90, 1997.

[52] Zhang, X. et al., Review of electric vehicle policies in China: Content summary and effect analysis. Renewable and Sustainable Energy Reviews, 70, pp. 698-714, 2017.

[54] Circular of the National Development and Reform Commission on Printing and Distributing Ctalog for the Guidance of the Industrial Development of Renewable Energy (Fa Gai Energy 2005 No. 2517).

[55] Yang, J. et al., The life-cycle energy and environmental emissions of a typical offshore wind farm in China. Journal of Cleaner Production, 180, pp. 316-324, 2018.

[56] Wang, Y. et al., China's electric car surge. Energy Policy, 102, pp. 486-490, 2017.

[57] Zhao, X., Zeng, Y. \& Zhao, D., Distributed solar photovoltaics in China: Policies and economic performance. Energy, 88, p. 572-583, 2015.

[58] Yuan, X. et al., The development of building energy conservation in China: A review and critical assessment from the perspective of policy and institutional systems. Sustainability, 9(9), pp. 1654, 2017.

[59] Sen, S. et al., Renewable energy scenario in India: Opportunities and challenges. Journal of African Earth Sciences, 122, pp. 25-31, 2016.

[60] Energy Conservation Act, 2001.

[61] The Integrated Energy Policy, 2006. 
[62] National Action Plan on Climate Change, 2008.

[63] 2011, Strategic Plan for New and Renewable Energy Sector for the Period 2011 2017.

[64] Saha, A. \& Talwar, K., India's response to climate change: The 2009 Copenhagen summit and beyond. National University of Juridical Sciences Law Review, 3(2), pp. $159,2010$.

[65] Badrinarayana, D., Transporting India into a new climate: The implications for energy law and policy. Cumberland Law Review, 40(1), pp. 119-133, 2009.

[66] Roy, A.G., Securing India's energy options in an interdependent world. Renewable Energy Law and Policy, 3(2), pp. 131-139, 2012.

[67] Mallah, S. \& Bansal, N.K., Renewable energy for sustainable electrical energy system in India. Energy Policy, 38(8), pp. 3933-3942, 2010.

[68] Rosha, A. \& Freestone, D., A., Green emerging market: India's experiments with market based mechanisms for climate mitigation. Carbon and Climate Law Review, 6(4), pp. 342-353, 2012.

[69] Electricity Act, 2003.

[70] Tariff Policy, 2006.

[71] Schmid, G., The development of renewable energy power in India: Which policies have been effective? Energy Policy, 45, pp. 317-326, 2012.

[72] Kar, S.K., Renewable energy market developments: A study of India. Renewable Energy Law and Policy, 4, pp. 238, 2015.

[73] Stern, A.C., History of air pollution legislation in the United States. Journal of the Air Pollution Control Association, 32(1), pp. 44-61, 1982.

[74] IEA, Global Renewable Energy, IEA Online. www.iea.org. Accessed on: 16 Dec. 2018.

[75] Air Pollution Control Act, 1955.

[76] EPA, Clean Air Act Text, EPA. www.epa.gov/clean-air-act-overview/clean-air-acttext. Accessed on: 16 Dec. 2018.

[77] Energy Policy Act of, 2005, 119 Stat. 594, Public Law 109-58.

[78] Energy Independence and Securities Act of 2007, 121 Stat. 1492, Public Law 110140.

[79] American Recovery and Reinvestment Act of 2009, 123 Stat. 115 Public Law 111-5.

[80] Clean Air Act of 2015 (as amended through Public Law 114-94).

[81] American Recovery and Reinvestment Act of 2009, 123 Stat. 115 Public Law 111-5, s. 406.

[82] Energy Independence and Securities Act of 2007, 121 Stat. 1492, Public Law 110140.

[83] Rogers-Hayden, T., Hatton, F. \& Lorenzoni, I., Energy security and climate change: Constructing UK energy discursive realities. Global Environmental Change, 21(1), pp. 134-142, 2011.

[84] Barton, J. et al., Transition pathways for a UK low-carbon electricity system: Comparing scenarios and technology implications. Renewable and Sustainable Energy Reviews, 82, p. 2779-2790, 2018.

[85] Nachmany M. et al., The 2015 global climate change legislation study: A review of climate change legislation in 99 countries. London School of Economics. www.lse.ac.uk. Accessed on: 17 Aug.t 2018.

[86] OECD, IEA \& IRENA, United Kingdom Renewable Energy Policy Framework Summary, IEA. www.iea.org. Accessed on: 16 Dec. 2018. 
[87] FitzPatrick, D., UK Legislative Framework for Renewable Energy, Taylor Wessing. www.united-kingdom.taylorwessing.com. Accessed on: 20 Dec. 2018.

[88] Climate Change Act, Cap 27, 2008.

[89] Cave, S., Climate Change Legislation and Targets, Northern Ireland Assembly Research and Information Service Research Paper 135/13, pp. 4, 2013.

[90] Directive 2009/28/EC of the European Parliament of the Council of 23 April, 2009.

[91] National Renewable Energy Action Plan for the United Kingdom, Article 4 of the Renewable Energy Directive 2009/28/EC at 6 and 114.

[92] DECC, UK Renewable Energy Roadmap Policy Paper, July 2011 at 9.

[93] Energy Act 2013 Cap 32.

[94] Anandarajah, G., Interactions and implications of renewable and climate change policy on UK energy scenarios. Energy Policy, 38(11), pp. 6724-6735, 2010.

[95] McHarg, A., Climate change constitutionalism? Lessons from the United Kingdom. Climate Law, 2, pp. 469-484, 2011.

[96] Hafez, A., Investigating the effectiveness of UK energy policy in promoting renewable investments and reducing carbon emissions. Zagreb International Review of Economics and Business, 17, pp. 1-25, 2014.

[97] Webb, J., Hawkey D. \& Tingey, M., Governing cities for sustainable energy: The UK case. Cities, 54, pp. 28-35, 2016.

[98] Liscow, Z. \& Karpilow, Q., Innovation snowballing and climate law. Washington University Law Review, 95, p. 387, 2017.

[99] Ranchordas, S., Innovation experimentalism in the age of the sharing economy. Lewis and Clark Law Review, 19(4), pp. 871-924, 2015.

[100] Mormann, F., Enhancing the investor appeal of renewable energy. Environmental Law, 42, p. 681-734, 2012.

[101] Wiseman, H., Expanding regional renewable governance. Harvard Environmental Law Review, 35, pp. 477-614, 2011. 